ORIGINAL ARTICLE / ARTIGO ORIGINAL

\title{
Tuberculosis fatality rates in the city of Campinas - São Paulo, Brazil, from 2001 to 2009
}

\author{
Taxas de letalidade por tuberculose na cidade \\ de Campinas, São Paulo, Brasil, de 2001 a 2009
}

Helenice Bosco de Oliveira', Letícia Marin-Léon' (D), Nanci Michele Saita" (D), Jonathan Eric Golub"II

ABSTRACT: Introduction: The mortality rate among tuberculosis patients (TB fatality) has been attributed to irregular chemotherapy, delay in diagnosis, multidrug resistance, and HIV coinfection. Objective: To analyze TB fatality rates by sex, clinical presentation and HIV coinfection in Campinas, São Paulo, Brazil. Methods: Cohorts of residents in the city of Campinas who either died during treatment for tuberculosis or had the disease confirmed after death were divided into three intervals: 2001-2003, 2004-2006, and 2007-2009. Data were obtained from the database of the Tuberculosis Surveillance System of the University of Campinas, and notifications were gathered through TB-WEB Health São Paulo Secretary. Statistical significance was determined using a chi-square test, considering $\mathrm{p}<0.05$. Results: Between 2001 and 2009, 3,416 TB patients were diagnosed: $2,827(82.8 \%)$ were new TB cases and $589(17.2 \%)$ were retreatments. Between the first and second triennium, the number of new patients decreased by $18 \%$, and $23 \%$ among retreatments. Between the second and third intervals, the reduction was $5 \%$ and $21 \%$, respectively. General case fatality rate declined from $11.4 \%$ to $9.9 \%$ across intervals, and was most significant among patients that had previously abandoned treatment $(17.3 \%$ to $5.1 \%$ ). Fatality rates among patients coinfected with TB-AIDS were $2-3$ times that of patients not infected with TB-AIDS throughout the intervals. Fatality between the first and third triennium among TB-AIDS co-infected patients declined (24.8\% to $19.5 \%)$, while increasing slightly among non-AIDS TB patients $(7.3 \%$ to $8 \%)$ during this period. Conclusion: Though mortality among TB-AIDS patients declined from 2001-2009, rates among non-AIDS TB remained stagnant. Improved TB diagnosis and treatment is needed to further decrease TB mortality in Campinas.

Keywords: Tuberculosis. AIDS. Case fatality rate. Comorbidity. Treatment. Mortality.

'Department of Collective Health, Universidade Estadual de Campinas - Campinas (SP), Brazil.

"Hospital de Clínicas, Universidade Estadual de Campinas - Campinas (SP), Brazil.

IIIJohns Hopkins Bloomberg School of Public Health - Baltimore (MD), United States.

Corresponding author: Helenice Bosco de Oliveira. Rua Waldyr Aparecido da Silva, 60, Residencial II, Condomínio Barão do Café, Barão Geraldo, CEP: 13085-065, Campinas, SP, Brazil. E-mail: helenice@unicamp.br

Conflict of interests: nothing to declare - Financial support: none. 
RESUMO: Introdução: A letalidade por tuberculose tem sido atribuída à quimioterapia irregular, à demora no diagnóstico, à multidrogarresistência, à coinfecção com o vírus da imunodeficiência humana (HIV). Objetivo: Analisar letalidade por tuberculose segundo sexo, apresentação clínica, presença da coinfecção pelo HIV, em Campinas, São Paulo, Brasil. Metodologia: Foram verificadas coortes de residentes em Campinas que morreram durante tratamento para tuberculose e aqueles notificados após óbito, agrupados em três intervalos: 2001-2003, 2004-2006 e 2007-2009. As informações foram obtidas no Banco de Dados para Vigilância da Tuberculose da Universidade Estadual de Campinas (UNICAMP), com captação das notificações no Sistema de Notificação e Acompanhamento de Casos de Tuberculose da Secretaria Estadual de Saúde de São Paulo. A significância estatística foi verificada pelo teste $\chi^{2}$ considerando $\mathrm{p}<0,05$. Resultados: Entre 2001 e 2009, foram diagnosticados 3.416 pacientes com tuberculose: $2.827(82,8 \%)$ sem tratamento anterior e 589 (17,2\%) com retratamentos. Entre o primeiro e o segundo triênio, o número de pacientes novos diminuiu $18 \%$ sem tratamento anterior e $23 \%$ entre retratamentos. Entre o segundo e o terceiro intervalo, a redução foi de 5 e $21 \%$, respectivamente. A letalidade geral declinou de 11,4 para $9,9 \%$, diferença mais significante entre os que haviam abandonado tratamento anteriormente (17,3 para 5,1\%). A letalidade entre pacientes com coinfecção tuberculose-síndrome da imunodeficiência adquirida (Aids) foi 2-3 vezes maior que entre tuberculose sem aids durante todo o período estudado. A letalidade entre o primeiro e o terceiro triênio declinou no grupo com tuberculose-aids (24,8 para 19,5\%), enquanto teve ligeiro aumento entre tuberculose sem aids (7,3 para 8\%). Conclusão: Embora a mortalidade entre pacientes com tuberculose-aids tenha diminuído de 2001-2009, as taxas no grupo tuberculose sem aids permaneceram estagnadas. Melhorias no diagnóstico e no tratamento são necessárias para a redução da mortalidade entre pacientes com tuberculose em Campinas.

Palavras-chave: Tuberculose. Aids. Letalidade. Comorbidade. Tratamento. Mortalidade.

\section{INTRODUCTION}

Brazil still remains on the World Health Organization's list of 22 high-burden tuberculosis (TB) countries, although the country has successfully met the Stop TB Partnership target of a $50 \%$ reduction in the mortality rate by $2015^{1}$.

The emergence of the HIV epidemic in the 1980s led to global changes in the epidemiologic trend of tuberculosis morbidity and mortality, reversing decades of declining rates. Prior to the HIV epidemic, TB surveillance and control programs were shortchanged as resources were shifted from the TB program to other programs ${ }^{2}$, thus setting the stage for a reemerging epidemic in the late $1980 \mathrm{~s}^{3,4}$. The advent of antiretroviral treatment (ART) programs in the mid 1990s helped to decrease TB mortality among TB-AIDS patients in Brazil ${ }^{5}$, particularly because Brazil took the bold step of paying for ART for patients in need ${ }^{6}$. Furthermore, the expansion of the WHO's DOTS strategy significantly impacted TB mortality worldwide ${ }^{7}$.

In Campinas, a large industrial city in the state of São Paulo, the richest in the country, a reduction in case fatality rates was observed between 1993 to 2000 from $18.1 \%$ to $13.5 \%$. This reduction was determined to be related to the introduction of ART ${ }^{5}$. The Campinas health care system is well organized, and at present, primary care is offered at 65 clinics. As in all of Brazil, TB and HIV / AIDS laboratory exams and treatment are free. Treatment of 
drug sensitive pulmonary tuberculosis with standard anti-tuberculosis drugs is highly efficacious, though some patients receiving these drugs still die. We set out to determine mortality trends in Campinas, specifically, to describe TB case fatality rates by sex, clinical presentation and presence of HIV co-infection in the period of 2001 to 2009, stratified by triennium.

\section{METHODS}

TB morbidity and mortality data were abstracted from local registries for residents of Campinas city (the State of São Paulo, Brazil) from January 1, 2001 through December 31, 2009. The analysis included patients that died during treatment and those that were diagnosed after death. Prisoners and all patients with non-tuberculosis mycobacterium were excluded from the study.

Pulmonary TB cases were defined by a sputum positive smear and/or culture for mycobacteria (BK), or suggestive radiology images with respiratory complaints. Extra-pulmonary TB was defined by a positive smear/culture for BK in any secretion, liquid or tissue sample, from radiology, histology or laboratory analysis.

Since 1993, a TB Surveillance Data Bank has been kept by the State University of Campinas. Data were retrieved from the National Notification System (SINAN) administered by the Health Ministry through 2006, and since 2007 from the TB-WEB, run by the São Paulo Health Secretary.

The TB Surveillance Data Bank includes all variables registered in the case notification form, including registration date, smear and culture results, radiology and laboratory analysis, date treatment began, anti-tuberculosis drugs and treatment outcomes. TB-AIDS was defined by the assistant doctor and registered in the comorbidity item of the notification form.

The main demographic variables included in this analysis were sex, age, and primary health unit that reported the case. Health variables included type of entrance in the notification system - new case or history of previous treatment (relapse, dropout or failure), clinical presentation (pulmonary and extra-pulmonary), laboratory exams (smear, culture, HIV), presence of other diseases (AIDS, diabetes, alcoholism, etc.), and treatment outcome (cure, county transfer, dropout, death, failure). Thus death data registered in SINAN or TB-WEB underwent confirmation and eventual correction using SIM. The later was used to verify under-notification.

Data tabulation of new cases, relapse, dropout and failure among cases and deaths, calculation of case-fatality rates by period, and stratification by sex, period and clinical form was performed using Epi Info 6.04d and Microsoft Excel 2007 for three periods 2001-2003, 2004-2006 and 2007-2009. Statistical significance among proportions was determined using the chi square test $(\mathrm{p}<0.05)$. Trends were analyzed using the chi square test for linear trends by Epi Info Statcalc, version 6.04.

The project was approved by the Ethics Research Committee of the School of Medical Sciences at the State University of Campinas. 


\section{RESULTS}

Between 2001 and 2009, 3,416 TB cases were diagnosed. Of these, 2,827 (82.8\%) were newly diagnosed TB cases and 589 (17.2\%) were retreatment cases. Across the first 3-year intervals, new cases diminished $18 \%$, while retreatment cases declined $23 \%$. The decline was 5 and $21 \%$, respectively, between the second and third intervals. General case fatality rate had a slight but not significant decline from 11.4 to $9.9 \%$ between the first and third triennium. Prior treatment dropout was the only group where fatality rate diminished significantly, from 17.3 to $5.1 \%$. There was a decreasing linear trend for retreatment cases vs new cases $(p=0.038)$, and the same occurred for deaths $(p=0.038)$ (Table 1$)$.

Table 1. Tuberculosis patients, deaths, and fatality rates in the city of Campinas-SP-Brazil, 2001 to 2009.

\begin{tabular}{|c|c|c|c|c|c|c|c|}
\hline \multirow{2}{*}{ Variables } & \multicolumn{2}{|c|}{ 2001-2003 } & \multicolumn{2}{|c|}{ 2004-2006 } & \multicolumn{2}{|c|}{ 2007-2009 } & \multirow{2}{*}{ p-value } \\
\hline & $\mathrm{n}$ & $\%$ & $\mathrm{n}$ & $\%$ & $\mathrm{n}$ & $\%$ & \\
\hline \multicolumn{8}{|l|}{ Entrance } \\
\hline New case & 1088 & 81.4 & 891 & 82.4 & 848 & 84.9 & 0.087 \\
\hline Relapse & 111 & 8.3 & 92 & 8.5 & 69 & 6.9 & 0.336 \\
\hline Previous dropout & 133 & 10.0 & 95 & 8.8 & 79 & 7.9 & 0.198 \\
\hline Failure & 4 & 0.3 & 3 & 0.3 & 3 & 0.3 & 0.994 \\
\hline Total number of cases & 1336 & 100 & 1081 & 100 & 999 & 100 & \\
\hline \multicolumn{8}{|l|}{ Deaths } \\
\hline New case & 116 & 76.3 & 94 & 81.0 & 86 & 86.9 & 0.117 \\
\hline Relapse & 13 & 8.6 & 14 & 12.1 & 8 & 8.1 & 0.528 \\
\hline Previous dropout & 23 & 15.1 & 8 & 6.9 & 4 & 4.0 & 0.007 \\
\hline Failure & 0 & 0 & 0 & 0 & 1 & 1.0 & - \\
\hline Total number of deaths & 152 & 100 & 116 & 100 & 99 & 100 & \\
\hline \multicolumn{8}{|l|}{ Fatality rate } \\
\hline New case & \multicolumn{2}{|c|}{10.7} & \multicolumn{2}{|c|}{10.5} & \multicolumn{2}{|c|}{10.1} & 0.929 \\
\hline Relapse & \multicolumn{2}{|c|}{11.7} & \multicolumn{2}{|c|}{15.2} & \multicolumn{2}{|c|}{11.6} & 0.701 \\
\hline Previous dropout & \multicolumn{2}{|c|}{17.3} & \multicolumn{2}{|c|}{8.4} & \multicolumn{2}{|c|}{5.1} & 0.014 \\
\hline Failure & \multicolumn{2}{|c|}{-} & \multicolumn{2}{|c|}{-} & \multicolumn{2}{|c|}{33.3} & - \\
\hline General & \multicolumn{2}{|c|}{11.4} & \multicolumn{2}{|c|}{10.7} & \multicolumn{2}{|c|}{9.9} & 0.526 \\
\hline
\end{tabular}

Statcalc linear trend for retreatment patients vs new patients $p=0.038$; Statcalc linear trend for retreatment deaths vs new patient deaths $\mathrm{p}=0.038$. 
During the whole study period, $687(20.1 \%)$ patients were notified to have TB-AIDS and 2,729 (79.9\%) did not have the coinfection (Table 2$)$. Males constituted the vast majority of cases $(68.4 \%)$ and deaths $(74.1 \%)$, both among TB-AIDS and non-AIDS TB patients. The case fatality rate was more than double for TB-AIDS patients compared to non-AIDS

Table 2. Tuberculosis patients with and without AIDS, according to sex, death and fatality rates. Campinas, SP, Brazil, 2001 to 2009.

\begin{tabular}{|c|c|c|c|c|c|c|c|}
\hline \multirow{2}{*}{ Variables } & \multicolumn{2}{|c|}{ 2001-2003 } & \multicolumn{2}{|c|}{ 2004-2006 } & \multicolumn{2}{|c|}{ 2007-2009 } & \multirow{2}{*}{ p-value } \\
\hline & $\mathrm{n}$ & $\%$ & $\mathrm{n}$ & $\%$ & $\mathrm{n}$ & $\%$ & \\
\hline \multicolumn{8}{|c|}{ TB-AIDS } \\
\hline \multicolumn{8}{|c|}{ Patients $(\mathrm{N}=687)$} \\
\hline Female & 80 & 25.7 & 61 & 29.5 & 55 & 32.5 & \multirow{2}{*}{0.269} \\
\hline Male & 231 & 74.3 & 146 & 70.5 & 114 & 67.5 & \\
\hline Total & 311 & 100 & 207 & 100 & 169 & 100 & \\
\hline \multicolumn{8}{|c|}{ Deaths $(N=160)$} \\
\hline Female & 17 & 22.1 & 19 & 38.0 & 11 & 33.3 & \multirow{2}{*}{0.134} \\
\hline Male & 60 & 77.9 & 31 & 62.0 & 22 & 66.7 & \\
\hline Total & 77 & 100 & 50 & 100 & 33 & 100 & \\
\hline \multicolumn{8}{|c|}{ Fatality rate } \\
\hline Female & \multicolumn{2}{|c|}{21.3} & \multicolumn{2}{|c|}{31.1} & \multicolumn{2}{|c|}{20.0} & 0.283 \\
\hline Male & \multicolumn{2}{|c|}{26.0} & \multicolumn{2}{|c|}{21.2} & \multicolumn{2}{|c|}{19.3} & 0.318 \\
\hline Total & \multicolumn{2}{|c|}{24.8} & & & \multicolumn{2}{|c|}{19.5} & 0.406 \\
\hline \multicolumn{8}{|c|}{ non-AIDS TB } \\
\hline \multicolumn{8}{|c|}{ Patients $(\mathrm{N}=2,729)$} \\
\hline Female & 348 & 33.9 & 285 & 32.6 & 251 & 30.2 & \multirow{2}{*}{0.250} \\
\hline Male & 677 & 66.1 & 589 & 67.4 & 579 & 69.8 & \\
\hline Total & 1,025 & 100 & 874 & 100 & 830 & 100 & \\
\hline \multicolumn{8}{|c|}{ Deaths $(N=207)$} \\
\hline Female & 19 & 25.3 & 18 & 27.3 & 11 & 16.7 & \multirow{2}{*}{0.303} \\
\hline Male & 56 & 74.7 & 48 & 72.7 & 55 & 83.3 & \\
\hline Total & 75 & 100 & 66 & 100 & 66 & 100 & \\
\hline \multicolumn{8}{|c|}{ Fatality rate } \\
\hline Female & \multicolumn{2}{|c|}{5.5} & \multicolumn{2}{|c|}{6.3} & \multicolumn{2}{|c|}{4.4} & 0.615 \\
\hline Male & \multicolumn{2}{|c|}{8.3} & \multicolumn{2}{|c|}{8.2} & \multicolumn{2}{|c|}{9.5} & 0.658 \\
\hline Total & & & & & & & 0.876 \\
\hline
\end{tabular}

Statcalc linear trend for TB-AIDS male patients vs non-AIDS TB male patients $p<0.0001$; Statcalc linear trend for TB-AIDS male death vs non-AIDS TB male deaths $p<0.001$. 
TB patients in the first (24.8 and 7.3\%) and last triennium (19.5 and 8.0\%). In the first triennium, among TB-AIDS patients, male fatality rate was the highest (26\%). In the second triennium, the highest was among female (31.1\%). Non-AIDS TB men had higher fatality rates than women in all the trienniums. Male TB-AIDS patients compared to non-AIDS TB patients had a decreasing linear trend for cases and deaths $(\mathrm{p}<0.001)$ (Table 2$)$.

TB-AIDS patients had nearly twice or more than three times the fatality rate of nonAIDS TB patients, depending on the clinical form and period (Table 3). In 2001-2003, the

Table 3. Deaths and fatality rates among tuberculosis patients according to clinical presentation and AIDS comorbity. Campinas, SP, Brazil, 2001 to 2009.

\begin{tabular}{|c|c|c|c|c|c|c|c|}
\hline \multirow{2}{*}{ Variables } & \multicolumn{2}{|c|}{ 2001-2003 } & \multicolumn{2}{|c|}{ 2004-2006 } & \multicolumn{2}{|c|}{ 2007-2009 } & \multirow{2}{*}{ p-value } \\
\hline & $\mathrm{n}$ & $\%$ & $\mathrm{n}$ & $\%$ & $n$ & $\%$ & \\
\hline \multicolumn{8}{|c|}{ I. New cases } \\
\hline \multicolumn{8}{|c|}{ Pulmonary presentation } \\
\hline \multicolumn{8}{|l|}{ Patients } \\
\hline TB-AIDS & 176 & 18.9 & 92 & 12.5 & 97 & 13.5 & \multirow{3}{*}{$<0.001$} \\
\hline non-AIDS TB & 757 & 81.1 & 642 & 87.5 & 624 & 86.5 & \\
\hline Total & 933 & 100 & 734 & 100 & 721 & 100 & \\
\hline \multicolumn{8}{|l|}{ Deaths } \\
\hline TB-AIDS & 43 & 44.8 & 22 & 31.0 & 16 & 22.9 & \multirow{3}{*}{0.010} \\
\hline non-AIDS TB & 53 & 55.2 & 49 & 69.0 & 54 & 77.1 & \\
\hline Total & 96 & 100 & 71 & 100 & 70 & 100 & \\
\hline \multicolumn{8}{|l|}{ Fatality rate } \\
\hline TB-AIDS & \multicolumn{2}{|c|}{24.4} & \multicolumn{2}{|c|}{23.9} & \multicolumn{2}{|c|}{16.5} & 0.288 \\
\hline non-AIDS TB & \multicolumn{2}{|c|}{7.0} & \multicolumn{2}{|c|}{7.6} & \multicolumn{2}{|c|}{8.7} & 0.517 \\
\hline Total & \multicolumn{2}{|c|}{10.3} & & & \multicolumn{2}{|c|}{9.7} & 0.892 \\
\hline \multicolumn{8}{|c|}{ Extra-pulmonary presentation } \\
\hline \multicolumn{8}{|l|}{ Patients } \\
\hline TB-AIDS & 51 & 32.9 & 39 & 24.8 & 33 & 26.0 & \multirow{3}{*}{0.237} \\
\hline non-AIDS TB & 104 & 67.1 & 118 & 75.2 & 94 & 74.0 & \\
\hline Total & 155 & 100 & 157 & 100 & 127 & 100 & \\
\hline \multicolumn{8}{|l|}{ Deaths } \\
\hline TB-AIDS & 9 & 45.0 & 13 & 56.5 & 9 & 56.2 & \multirow{3}{*}{0.708} \\
\hline non-AIDS TB & 11 & 55.0 & 10 & 43.5 & 7 & 43.8 & \\
\hline Total & 20 & 100 & 23 & 100 & 16 & 100 & \\
\hline
\end{tabular}


Table 3. Continuation.

\begin{tabular}{|l|c|c|c|c|c|c|c|}
\multirow{2}{*}{ Variables } & \multicolumn{2}{|c|}{$2001-2003$} & \multicolumn{2}{|c|}{$2004-2006$} & \multicolumn{2}{|c|}{$2007-2009$} & \multirow{2}{*}{$\mathrm{p}$-value } \\
\cline { 2 - 7 } & $\mathrm{n}$ & $\%$ & $\mathrm{n}$ & $\%$ & $\mathrm{n}$ & $\%$ & \\
\hline
\end{tabular}

Fatality rate

\begin{tabular}{|l|c|c|c|c|}
\hline TB-AIDS & 17.6 & 33.3 & 27.3 & 0.225 \\
\hline non-AIDS TB & 10.6 & 8.5 & 7.5 & 0.728 \\
\hline Total & 12.9 & 14.7 & 12.6 & 0.855 \\
\hline
\end{tabular}

Pulmonary presentation

\begin{tabular}{|c|c|c|c|c|c|c|c|}
\hline \multicolumn{8}{|l|}{ Patients } \\
\hline TB-AIDS & 69 & 31.5 & 62 & 36.7 & 32 & 23.0 & \multirow{3}{*}{0.035} \\
\hline non-AIDS TB & 150 & 68.5 & 107 & 63.3 & 107 & 77.0 & \\
\hline Total & 219 & 100 & 169 & 100 & 139 & 100 & \\
\hline \multicolumn{8}{|l|}{ Deaths } \\
\hline TB-AIDS & 22 & 66.7 & 12 & 63.2 & 8 & 61.5 & \multirow{3}{*}{0.936} \\
\hline non-AIDS TB & 11 & 33.3 & 7 & 36.8 & 5 & 38.5 & \\
\hline Total & 33 & 100 & 19 & 100 & 13 & 100 & \\
\hline \multicolumn{8}{|l|}{ Fatality rate } \\
\hline TB-AIDS & \multicolumn{2}{|c|}{31.9} & \multicolumn{2}{|c|}{19.4} & \multicolumn{2}{|c|}{25.0} & 0.260 \\
\hline non-AIDS TB & \multicolumn{2}{|c|}{7.3} & \multicolumn{2}{|c|}{6.5} & \multicolumn{2}{|c|}{4.7} & 0.684 \\
\hline Total & \multicolumn{2}{|c|}{15.1} & \multicolumn{2}{|c|}{11.2} & \multicolumn{2}{|c|}{9.4} & 0.241 \\
\hline \multicolumn{8}{|c|}{ Extra-pulmonary presentation } \\
\hline \multicolumn{8}{|l|}{ Patients } \\
\hline TB-AIDS & 15 & 51.7 & 14 & 66.7 & 7 & 58.3 & \multirow{3}{*}{0.572} \\
\hline non-AIDS TB & 14 & 48.3 & 7 & 33.3 & 5 & 41.7 & \\
\hline Total & 29 & 100 & 21 & 100 & 12 & 100 & \\
\hline \multicolumn{8}{|l|}{ Deaths } \\
\hline TB-AIDS & 3 & 100 & 3 & 100 & 0 & - & - \\
\hline non-AIDS TB & 0 & - & 0 & - & 0 & - & - \\
\hline Total & 3 & 100 & 3 & 100 & 0 & - & - \\
\hline \multicolumn{8}{|l|}{ Fatality rate } \\
\hline TB-AIDS & \multicolumn{2}{|c|}{20.0} & \multicolumn{2}{|c|}{21.4} & \multicolumn{2}{|c|}{ - } & 0.417 \\
\hline non-AIDS TB & \multicolumn{2}{|c|}{ - } & \multicolumn{2}{|c|}{ - } & \multicolumn{2}{|c|}{ - } & - \\
\hline Total & \multicolumn{2}{|c|}{10.3} & \multicolumn{2}{|c|}{14.3} & \multicolumn{2}{|c|}{ - } & 0.404 \\
\hline
\end{tabular}

Statcalc linear trend for new pulmonary TB-AIDS patients vs non-AIDS TB patients $p=0.001$; Statcalc linear trend for new pulmonary TB-AIDS deaths vs non-AIDS TB deaths $p=0.002$. 
highest fatality rate was among TB-AIDS retreatment cases with a pulmonary presentation $(31.9 \%)$ (Table 3). From 2004 onwards, the highest fatality rates were among TB-AIDS new cases with an extra-pulmonary form (33.3 and 27.3\% respectively) (Table 3 ).

There were 488 new TB-AIDS patients, 365 (74.8\%) of which had a pulmonary presentation. This proportion was $86.5 \%$ among the 2,339 non-AIDS TB patients. Comparing the third with the first triennium, these cases decreased by $44.9 \%$ among TB-AIDS patients and $17.6 \%$ among non-AIDS TB patients. A decreasing linear trend was observed for new cases of pulmonary TB-AIDS and deaths when compared with non-AIDS TB cases $(\mathrm{p}=0.001$ and $\mathrm{p}=0.002)($ Table 3$)$.

\section{DISCUSSION}

In Campinas, the total number of TB patients has diminished in relation to the annual mean of the first years (1997-2000) $)^{5}$ with Highly Active Antiretroviral Therapy (HAART) both among male and female patients with and without HIV.

Fatality rates in the period from 2001 to 2009 were lower than in the period from 1997-2000 among TB non-AIDS patients ${ }^{5}$. No consistent differences in the trend of fatality rates were observed among the sexes.

The predominance of the male sex among both TB non-AIDS and TB-AIDS patients is a fact observed by many authors ${ }^{8,9}$ and also previously described in the city ${ }^{5}$.

Before HAART in Campinas, the number of TB-AIDS patients represented $28.7 \%$ of all TB cases $^{5}$. This proportion dropped to $24.6 \%$ after HAART was introduced ${ }^{5}$. In the years covered by this study, it gradually decreased to $23.3 \%$ (2001-2003), 19.1\% (2004-2006) and $16.9 \%$ (2007-2009).

In consonance with several studies ${ }^{10}$ performed in Campinas, TB-AIDS cases presented much higher fatality rates (19.5 to $24.8 \%$ ) than TB non-AIDS cases (7.3 to 8.0\%). Similar fatality rates were observed in 2000-2006 in the State of Espírito Santo, Brazil (28.8\% among TB-AIDS patients and 5.9\% among non-AIDS TB patients $)^{11}$. In a sample of 2,473 hospitalized patients in the city of São Paulo, Brazil in 2001, fatality rates were similar for TB-AIDS cases $(24 \%)$ but much higher among non-AIDS TB cases $(15.1 \%)$, which can be explained by the severity of the clinical presentation of patients that need hospital care, considering that disseminated TB that killed $66 \%$ of the patients with this clinical form ${ }^{12}$. In a cohort of 887 pulmonary TB patients followed for two years in a Tanzanian city ${ }^{13}$, fatality among the TB-AIDS cases (29.7\% in 471 patients) was similar to that in Campinas, and quite lower among non-AIDS TB cases (3.6\% in 416 patients). In spite of this later fatality ${ }^{13}$, it can be argued that important efforts need to be done in Campinas to reduce fatality among pulmonary TB patients without HIV.

The lack of significant reduction in the fatality rates of TB-AIDS in Campinas denotes no real improvement in treatment. On the other hand, the reduction in the proportion of patients with TB-AIDS represents an advancement in the prevention and control of AIDS, 
since less people become ill with TB-AIDS. In New York City, between 1995 and 2004, the fatality rate of TB-AIDS decreased from $26 \%$ to $14 \%{ }^{14}$. In Cambodia, a study of 490 nonAIDS TB patients and 339 TB-AIDS patients treated in TB clinics, observed a case-fatality rate of $37 \%$ in 2004 when HAART had not been implemented, and a $18 \%$ rate in 2005 , when it was used along with anti-TB treatment ${ }^{15}$. In the same years, among non-AIDS TB patients, the fatality rate remained at $5 \%{ }^{15}$. As observed by Lawn et al. ${ }^{16}$, to reduce mortality among AIDS patients, early diagnosis and ARV treatment must be improved, because mortality is associated with low CD4 cell count, less than 50 cells/ $\mu$ l, and an advanced stage of the disease. In Rio de Janeiro, Brazil, the proportion of AIDS patients with tuberculosis diagnosed annually decreased from $24.4 \%$ in 1995 to $15.2 \%$ in 1998, but from 1995 to 2004, there was no further improvement. Pacheco et al. ${ }^{17}$ pointed out that to reduce TB incidence among AIDS patients, earlier HIV / AIDS diagnosis and ART initiation is needed.

Although extra-pulmonary TB is more difficult to diagnose than pulmonary TB, in Campinas, their fatality rates were not significantly different among new and retreatment cases, and among non-AIDS TB and TB-AIDS cases. Since clinical presentation does not contribute to differences in fatality rates, it may be observed that once extra-pulmonary presentations are diagnosed, they are adequately treated.

In essence, treating patients with a previous history of TB might be more difficult than treating new cases, because of immunologic deficiencies among relapse patients, resistance to adherence among dropouts, or multidrug resistance among failures. Nevertheless, in Campinas, a significant reduction in fatality rates among patients with previous dropout $(\mathrm{p}<0.014)$ was observed. This data points to better management of retreatment patients, with a provable improvement in the quality of management, resulting in higher adherence to treatment.

Most conditions related to higher TB incidence and TB fatality are poor living conditions, being homeless, unhealthy lifestyle (smoking and alcoholism) ${ }^{1}$, all of which are in some degree related to poor schooling ${ }^{18,19}$. Health Education is an important issue in the management of TB. It has been observed that people that have a general knowledge about TB have better care-seeking behavior and understand the need of daily and prolonged treatment ${ }^{20}$, having higher adherence to treatment. In Rio de Janeiro, in populations living in slums, it was observed that when community health workers were engaged in Directly Observed Treatment Short-courses (DOTS), the patients adherence to treatment was higher ${ }^{21}$. These professionals are able to communicate with efficiency among poor people, reducing social inequalities in health.

Interrupting treatment during the intensive phase has been associated with increased risk of death ${ }^{22}$, and it represents lack of adherence. In Campinas, as in all of Brazil, DOTS is considered to be present when 24 doses are supervised in the first 60 days of treatment ${ }^{23}$. This lower number of supervised doses might be a point to be improved in order to reduce morbidity and mortality. In Rio de Janeiro, patients' engagement in DOTS conducted by community health workers resulted in higher cure rates and lower fatality, when compared to self-administered therapy ${ }^{21}$. 
Some limitations of this manuscript, with secondary data, include lack of information to track dropouts and transfers. As such, our fatality rates may be underreported. Also, the lack of information from DOTS at an individual level impairs the possibility of evaluating the importance of this factor. In TB-AIDS cases, the lack of clinical severity variables, such as CD4 cell count, is a barrier in understanding the degree in which it contributes to fatality rates.

\section{CONCLUSION}

Although the absolute number of cases, mainly those with a pulmonary presentation and with TB-AIDS, decreased in Campinas, non-AIDS TB and TB-AIDS fatality rates have not diminished, except for previous dropouts, which remain much higher than in other countries or cities reported in this paper. Epidemiological surveillance has an important role in evaluating the adequate registration of the compulsory notification form and in monitoring TB cases reported in a municipality.

Considering that TB is curable, and thus deaths from this disease are avoidable, the quality of the diagnosis process - treatment initiation and adequate quality of treatment, including direct supervision according to the terms defined by the WHO and patient follow-up - must be constantly revised in order to decrease fatality rates in Campinas.

\section{ACKNOWLEDGEMENTS}

We thank the coordinators of the TB State Program who gave us access to the TB-WEB, enabling the direct research of notification forms in order to maintain the TB Surveillance Data Bank of the State University of Campinas. We are grateful to ICOHRTA-Brazil (International Clinical, Operational and Health Services Research training awards for AIDS and Tuberculosis) and John's Hopkins University for having awarded two of the authors with a summer training program on TB at John's Hopkins University.

\section{REFERENCES}

1. World Health Organization. Global tuberculosis control: WHO report 2012 [Internet]. WHO; 2012 [cited on March 1, 2013]. Available from: http://who.int/tb/ publications/global_report//gtbr12_main.pdf

2. Brudney K, Dobkin J. Resurgent tuberculosis in New York City: HIV, homelessness and the decline of TB control program. Am Rev Resp Dis. 1991; 144: 745-9. https: / / doi.org/10.1164/ajrccm/144.4.745
Ruffino-Netto A. Avaliação do excesso de casos de tuberculose atribuídos a infecção HIV/AIDS: ensaio preliminar. Rev Saúde Pública. 1995; 29(4): 279-82. http:/ / dx.doi.org/10.1590/S0034-89101995000400004

4. Antunes JLF, Waldman EA. Tuberculosis in the twentieth century: time-series mortality in São Paulo, Brazil, 1900-97. Cad Saúde Pública. 1999; 15(3): 463-76. http: / / dx.doi.org/10.1590/S0102-311X1999000300003 
5. Oliveira HB, Marín-León L, Cardoso JC. Differences in mortality profile of tuberculosis patients related to tuberculosis-AIDS co-morbidity. Rev Saúde Pública. 2004; 38(4): 503-10. http://dx.doi.org/10.1590/ S0034-89102004000400004

6. Golub JE, Saraceni V, Cavalcante SC, Pacheco AG, Moulton LH, King BS, et al. The impact of antiretroviral therapy and isoniazid preventive therapy on tuberculosis incidence in HIV-infected patients in Rio de Janeiro, Brazil. AIDS. 2007; 21(11): 1441-8. https:// dx.doi. org/10.1097\%2FQAD.0b013e328216f441

7. Webb RM, Penman A, Holcombe M, Dobbs T, Mathew TA. Decline in tuberculosis with 19 years of universal directly observed therapy in a comprehensive statewide program. Int J Tuberc Lung Dis. 2011; 15(6): 848-50. https: / / doi.org/10.5588/ijtld.10.0381

8. Borgdorff MW, Nagelkerke NJD, Dye C, Nunn P. Gender and tuberculosis: a comparison of prevalence surveys with notification data to explore sex differences in case detection. Int J Tuberc Lung Dis. 2000; 4(2): 123-32.

9. Neyrolles O, Quintana-Murci L. Sexual Inequality in Tuberculosis. PLoS Med. 2009; 6(12): e100199. https: / / doi.org/10.1371/journal.pmed.1000199

10. Kwan CK, Ernst JD. HIV and Tuberculosis: a Deadly Human Syndemic. Clin Microbiol Rev. 2011; 24: 351 76. https:// doi.org/10.1128/CMR.00042-10

11. Prado TN, Caus AL, Marques M, Maciel EL, Golub JE, Miranda AE. Epidemiological profile of adult patients with tuberculosis and AIDS in the state of Espírito Santo, Brazil: Cross-referencing tuberculosis and AIDS databases. J Bras Pneumol. 2011; 37(1): 93-9.

12. Galesi VMN, Almeida MMMB. Indicators of tuberculosis morbimortality in hospitals in the city of São Paulo. Rev Bras Epidemiol. 2007; 10(1): 48-55. http:/ / dx.doi.org/10.1590/S1415-790X2007000100006

13. Mugusi F M, Mehta S, Villamor E, Urassa W, Saathoff $\mathrm{E}$, Bosch RJ, et al. Factors associated with mortality in HIV-infected and uninfected patients with pulmonary tuberculosis. BMC Public Health. 2009; 9: 409. https: / / doi.org/10.1186/1471-2458-9-409

14. King L, Munsiff SS, Ahuja SD. Achieving international targets for tuberculosis treatment success among HIVpositive patients in New York City. Int J Tuberc Lung Dis. 2010; 14(2): 1613-20.

15. Eng B, Cain KP, Nong K, Chhum V, Sin E, Roeun S, et al. Impact of a public antiretroviral program on TB/HIV mortality: Banteay Meanchey, Cambodia. Southeast Asian J Trop Med Public Health. 2009; 40: 89-92.

16. Lawn SD, Harries AD, Anglaret X, Myer L, Wood R. Early mortality among adults accessing antiretroviral treatment programmes in sub-Saharan Africa. AIDS. 2008; 22(15): 1897-908. https:/ / dx.doi. org/10.1097\%2FQAD.0b013e32830007cd

17. Pacheco AG, Durovni B, Cavalcante SC, Lauria LM, Moore RD, Moulton LH, et al. AIDS-related tuberculosis in Rio de Janeiro, Brazil. PLoS One. 2008; 3(9): 1-6. https:// doi.org/10.1371/journal.pone.0003132

18. Córdoba-Doña JA, Novalbos-Ruiz JP, Suárez-Farfante J, Andérica-Frías G, Escolar-Pujolar A. Social inequalities in HIV-TB and non-HIV TB patients in two urban areas in southern Spain: multilevel analysis. Int J Tuberc Lung Dis. 2012; 16(3): 342-47. https:// doi. org/10.5588/ijtld.11.0137

19. David AM, Mercado SP, Becker D, Edmundo K, Mugisha F. The prevention and control of HIV/ AIDS, TB and vector-borne diseases in informal settlements: challenges, opportunities and insights. J Urban Health. 2007; 84(Suppl. 1): i65-i74. https: / / dx.doi.org/10.1007\%2Fs11524-007-9183-5

20. Allebeck P. Delay in tuberculosis care: one link in a long chain of social inequities. Eur J Public Health. 2007; 17(5): 409. https: / / doi.org/10.1093/eurpub/ckm046

21. Ferreira V, Brito C, Portela M, Escosteguy C, Lima $S$. DOTS in primary care units in the city of Rio de Janeiro, Southeastern Brazil. Rev Saúde Pública. 2011; 45(1): 40-8. http://dx.doi.org/10.1590/ S0034-89102010005000055

22. Nahid P, Jarlsberg LG, Rudoy I, de Jong BC, Unger A, Kawamura LM, et al. Factors associated with mortality in patients with drug-susceptible pulmonary tuberculosis. BMC Infect Dis. 2011; 11: 7-12. https:/ / doi.org/10.1186/1471-2334-11-1

23. Brasil. Ministério da Saúde. Secretaria de Vigilância em Saúde. Plano Nacional de Controle da Tuberculose 2011. Manual de recomendações para o controle da tuberculose no Brasil [Internet]. Brasília, 2011 [cited on March 10, 2012]. Available from: http:/ / bvsms.saude. gov.br/bvs/publicacoes/manual_recomendacoes_ controle_tuberculose_brasil.pdf

Received on: 03/19/2013

Accepted on: 08/05/2015

Author's contributions: All of the authors contributed to the paper, but the first and the second authors came up with the subject matter, since is a continuation of their work from a previous decade. The third author did her master's degree working with HIV-TB co-infection in the city of Campinas and the fourth author assisted in reviewing the material. 